\title{
Wacana Budaya Suku Sasak di Desa Sade dalam Detik.com
}

\author{
Regita Nada Yalatama, Nuryah Asri Sjafirah, dan Rinda Aunillah \\ Fakultas Ilmu Komunikasi, Universitas Padjadjaran \\ regtnada@gmail.com
}

\begin{abstract}
Media coverage of Sade Village often discusses a village that upholds local customs. The culture of Sade Village in media coverage is considered a culture that is not eroded by modernization. In fact, two studies related to the ethnography of Sasak culture mentioned that Sasak's culture tribe has been eroded by modernization. Detik.com is an online media that published news related to tourist attractions in Sade Village as a village with a culture that is still original and has not been eroded by modernization. This research used Norman Fairclough's critical discourse analysis model to analyze the cultural discourse of the Sasak Tribe in Sade Village news, which is also related to detik.com's dicourse in representing the Sasak culture. The analysis was carried out by three levels: text level, discourse practice level and sociocultural level. The results showed that detik.com in representing the culture of the Sasak Tribe only displayed positive images of Sade Village. At the text level, detik.com influenced readers regarding Sasak Tribe culture that is unique. At the level of discourse practice, the production of Sade Village news on the detik.com news portal is aimed to develop Indonesian culture. While at the sociocultural level, the macro aspect influenced detik.com in representing the culture of the Sasak tribe in Sade Village. Therefore, the discussion of Sasak Tribe culture in the coverage of Sade Village in detik.com, represents a positive image to promote Sade Village which is influenced by internal and external factors.
\end{abstract}

Keywords: culture; critical discourse analysis; Sade Village; travel journalism; travel news

\begin{abstract}
Abstrak
Desa Sade dalam pemberitaan media seringkali diwacanakan sebagai desa yang memegang teguh adat dan istiadat setempat. Budaya Desa Sade dalam pemberitaan media dianggap sebagai budaya yang tidak tergerus modernisasi. Padahal, dua penelitian terkait etnografi budaya Suku Sasak menyatakan bahwa budaya Suku Sasak di Desa Sade dinilai telah tergerus modernisasi. Detik.com merupakan salah satu media online yang mempublikasikan berita terkait tempat wisata Desa Sade sebagai desa dengan budaya yang masih asli dan belum tergerus modernisasi. Penelitian ini menggunakan analisis wacana kritis model Norman Fairclough untuk menganalisis wacana budaya Suku Sasak dalam pemberitaan Desa Sade, yang juga berkaitan dengan wacana detik. com dalam merepresentasikan budaya Suku Sasak. Analisis dilakukan dengan menguji tiga tahap, yaitu level teks, level praktik wacana dan level sosiokultural. Hasil penelitian menunjukkan bahwa detik.com dalam merepresentasikan budaya Suku Sasak hanya menampilkan citra positif dari Desa Sade. Pada level teks, detik.com memengaruhi pembaca terkait budaya Suku Sasak yang dianggap unik sebagai bagian dari wacana poskolonial. Pada level praktik wacana, produksi berita Desa Sade pada portal berita detik.com ditujukan untuk memajukan budaya Indonesia. Sementara pada level sosiokultural, aspek makro memengaruhi detik.com dalam merepresentasikan budaya Suku Sasak di Desa Sade. Maka, detik.com ketika mewacanakan budaya Suku Sasak dalam pemberitaan Desa Sade, merepresentasikan citra positif untuk mempromosikan Desa Sade yang dipengaruhi oleh faktor internal dan eksternal.
\end{abstract}

Kata kunci: analisis wacana kritis; berita wisata; budaya; Desa Sade; jurnalisme perjalanan

Korespondensi: Regita Nada Yalatama, S.I.Kom, Fakultas Ilmu Komunikasi, Universitas Padjadjaran, J1. Raya Bandung Sumedang KM.21, Kec. Jatinangor, Kabupaten Sumedang, Jawa Barat, 45363, Email: regtnada@gmail.com

Menyerahkan: Desember 2020, Diterima: April 2021, Terbit: Juli 2021

ISSN: 2549-0559 (cetak), ISSN: 2549-1946 (online), Website: http://jurnal.unpad.ac.id/kajian-jurnalisme 
DOI: $10.24198 / \mathrm{jkj} . v 5 \mathrm{i} 1.31320$

\section{PENDAHULUAN}

Pers dan media memiliki posisi yang cukup strategis dalam perkembangan industri pariwisata karena menjadi bagian dalam lingkup pentahelix industri pariwisata bersama dengan pemerintah, pelaku bisnis, akademisi dan komunitas (Fadhillah, Sjafirah, \& Basith, 2019). Media memiliki peranan penting dalam perkembangan pariwisata dengan menyalurkan informasi terkait wisata yang dapat menghibur, mengedukasi dan mempersuasi pembacanya. Tak jarang, informasi wisata yang diberikan oleh media beririsan dengan tujuan promosi terhadap suatu wilayah. Jika mengikuti aturan jurnalistik, seharusnya berita wisata yang dipublikasikan oleh media harus sesuai dengan kaidah-kaidah jurnalistik. Hanya saja, berita wisata yang seharusnya masuk pada jurnalisme perjalanan, saat ini memiliki konsep yang samar.

Berdasarkan pengamatan Sulhan (2017), media merupakan pencerita. Menurut Sulhan, media memiliki peran dalam mempromosikan destinasi wisata. Media dapat menceritakan pengalaman seseorang mengenai sebuah destinasi wisata melalui rangkaian narasi yang unik dan khas. Pengalaman wisata yang diceritakan di media, memantik kesamaan pengalaman dan referensi dari satu wisatawan ke wisatawan lainnya (Sulhan, 2017). Menurut Sulhan, pertukaran pengalaman yang ditampilkan di media digital telah membentuk kekuatan promosi destinasi pariwisata Indonesia yang berkembang menuju arah yang menggembirakan. Maka, tak heran jika berita wisata yang ditampilkan di media saat ini mengarah pada 'kesenangan pribadi' dibandingkan kepentingan publik.

Berita wisata sebagai bagian dari jurnalisme perjalanan seharusnya lebih bertanggung jawab kepada publik. Jika merujuk pada konsep jurnalisme, maka jurnalisme perjalanan seharusnya mengacu pada parameter jurnalisme tentang perilaku etis dan pencarian fakta (Hanusch, 2010). Maka, hal tersebut berlaku untuk berita wisata. Menurut Hanusch (2010), jurnalisme perjalanan harus memiliki empat dimensi, yaitu representasi budaya asing, standar etika, orientasi pasar dan aspek motivasi. Namun, berita wisata yang dipublikasikan media pada saat ini dianggap dapat ditulis oleh siapa saja dan jarang memenuhi empat dimensi jurnalisme perjalanan.

Saat ini, meski sudah banyak media yang menyediakan rubrik khusus terkait pemberitaan wisata, namun secara umum media hanya menggambarkan kesenangan yang dialami oleh penulisnya sehingga pemberitaan menjadi subjektif. Salah satu contoh pemberitaan wisata yang hanya menggambarkan kesenangan penulisnya, yaitu pemberitaan wisata Desa Sade oleh media online. Desa Sade merupakan wisata budaya yang terletak di Desa Rembitan, Kecamatan Pujut, Kabupaten Lombok Tengah (Zakaria, 2018). Jika melihat pemberitaan wisata Desa Sade, maka isi pemberitaan hanya berisi ulasan penulis ketika mengunjungi Desa Sade.

Representasi Desa Sade yang ditampilkan oleh media lekat kaitannya dengan budaya Suku Sasak sebagai budaya yang dianggap masih dipegang teguh oleh warga setempat. Desa Sade dikenal sebagai desa tradisional yang isinya merupakan sebuah perkampungan yang masih mencoba mempertahankan keaslian budaya Suku Sasak sejak zaman pemerintah Kerajaan Pejanggik di Praya (Zakaria, 2018). Sebagai wisata budaya, Desa Sade tidak pernah lepas dari pemberitaan mengenai budaya yang ada di dalamnya. Namun, representasi Desa Sade oleh media memiliki ketimpangan dengan fakta yang sebenarnya terjadi di Desa Sade.

Detik.com merupakan salah satu media yang berperan dalam memberitakan Desa Sade dalam rubrik khusus bernama detiktravel. Representasi yang dimunculkan detik.com terkait Desa Sade meliputi Budaya Suku Sasak yang dianggap masih asli dan belum tergerus modernisasi. Budaya menurut Said (1993) terbagi dalam dua konsep, yakni budaya sebagai praktik yang mencakup ranah ekonomi, sosial dan politik, serta budaya yang dianggap sebagai sumber identitas, seperti adat dan tradisi. Pada penelitian ini, wacana budaya yang dimaksud 
merupakan budaya dalam konsep kedua yang mengarah pada adat dan tradisi, yang juga digambarkan oleh detik.com sebagai budaya yang merujuk pada wacana eksotisme.

Detik.com merepresentasikan Desa Sade sebagai desa yang eksotis, di mana budaya Suku Sasak yang ada di Desa Sade dianggap masih asli, belum tergerus modernisasi dan masih dipegang teguh oleh masyarakat setempat. Berikut contoh representasi Desa Sade yang dimunculkan oleh detik.com: "Desa Sade adalah salah satu perkampungan di Lombok yang masih memegang teguh tradisi adatnya secara turun-temurun. Ada banyak tradisi unik di sini" (Zaakiyah, 2019).

Penggunaan kata masih memegang teguh tradisi dan unik dalam contoh di atas, menggambarkan Desa Sade sebagai desa yang eksotis. Secara tidak langsung, detik.com menggambarkan Desa Sade sebagai desa yang tidak tergerus modernisasi. Representasi yang dimunculkan oleh detik.com berkaitan dengan peran detik.com dalam merepresentasikan wisata Desa Sade kepada khalayak. Detik.com cenderung memberikan berita yang bersifat menghibur dan merujuk pada kegiatan promosi dengan memunculkan citra positif terkait budaya Suku Sasak di Desa Sade.

Di sisi lain, representasi budaya Suku Sasak yang ditampilkan oleh detik.com cukup berbeda dengan hasil dua penelitian akademis terkait etnografi budaya Suku Sasak. Pada penelitian berjudul "Dampak Sosial Budaya Pengembangan Dusun Sade sebagai Dusun Wisata di Kabupaten Lombok Tengah", Sari dan Nugroho mengungkapkan perubahan dampak sosial budaya yang terjadi di Desa Sade. Sari dan Nugroho melakukan pendekatan kualitatif dan mengumpulkan data melalui observasi, wawancara dan dokumentasi. Pada penelitiannya, Sari dan Nugroho menggunakan konsep dampak sosial budaya, konsep kebudayaan dan konsep desa wisata. Berdasarkan hasil penelitian, status Dusun Sade yang ditetapkan sebagai dusun wisata telah mengubah budaya yang ditranformasikan oleh masyarakat melalui interaksi sosial dengan wisatawan (Sari \& Nugroho, 2018).

Penelitian terkait perubahan lanskap budaya Desa Sade juga disampaikan oleh Agus Sukandar dalam penelitian berjudul "Menggagas Pelestarian Permukiman Tradisional Dusun Sade sebagai Lansekap Budaya yang Mampu Mengantisipasi Kebutuhan Penghuninya”. Agus Sukandar menyatakan bahwa telah terjadi perubahan lanskap budaya yang terjadi di Desa Sade. Perubahan yang terjadi di Desa Sade meliputi perubahan tata kehidupan, tata lingkungan, tata hijau, bentuk bangunan dan penggunaan material (Sukandar, 2017). Berdasarkan dua penelitian tersebut, Desa Sade dianggap telah mengalami perubahan budaya akibat modernisasi. Sementara detik.com merepresentasikan Desa Sade sebagai desa yang kental akan budaya, seakan belum tergerus modernisasi.

Detik.com juga cukup rutin dalam mempublikasikan berita terkait Desa Sade. Sejauh ini, telah dimuat 93 berita yang berkaitan dengan nama Desa Sade selama periode 2010 hingga 2020. Jumlah berita terkait Desa Sade periode 2019 di detik.com lebih banyak dibandingkan tahun sebelumnya, yakni sembilan berita (Olahan Peneliti, 2020). Jumlah tersebut menjadi pertimbangan peneliti dalam memilih periode 2019 di detik.com. Dari sembilan berita, peneliti memilih empat berita yang paling merepresentasikan budaya Suku Sasak Sade sebagai budaya yang masih asli.

Penelitian dilakukan dengan menggunakan analisis wacana kritis model Norman Fairclough. Tujuan dari penelitian ini yaitu untuk menganalisis wacana budaya Suku Sasak yang ditampilkan oleh detik.com dalam pemberitaan Desa Sade. Melalui analisis wacana, peneliti ingin melihat bagaimana budaya (khususnya budaya eksotis) Suku Sasak direpresentasikan oleh detik.com. Fairclough menyebut wacana sebagai bentuk "praktik sosial" yang berimplikasi adanya dialektika antara bahasa dan kondisi sosial (Fauzan, 2014). Penggunaan analisis 
wacana memungkinkan peneliti untuk mengetahui alasan detik.com merepresentasikan budaya eksotis Suku Sasak sebagai budaya yang masih asli, sekaligus melihat peran detik.com dalam merepresentasikan budaya eksotis Suku Sasak di Desa Sade.

Penelitian ini mengkaji tiga aspek dengan menggunakan analisis wacana kritis model Norman Fairclough, yaitu level teks, level praktik wacana dan level praktik sosiokultural. Pada analisis teks, aspek yang dikaji berkaitan dengan penggunaan kosa kata, tata bahasa, metafora dan sitaksis. Pada level praktik wacana, analisis yang dilakukan berkaitan dengan produksi berita yang dilakukan oleh detik.com, yang juga berkaitan dengan intertekstualitas. Sementara pada level praktik sosiokultural, analisis yang dilakukan berkaitan dengan realitas sosiokultural (aspek makro), yang menghubungkan antara teks dan konteks.

Mengingat berita wisata juga berkaitan dengan konsep jurnalisme perjalanan yang disampaikan oleh Hanusch, maka konsep jurnalisme perjalanan juga menjadi alat bagi peneliti untuk menganalisis berita Desa Sade sacara lebih mendalam. Hanusch membedakan apa yang disebut berita wisata dan tulisan wisata. Sebagaimana disampaikan oleh Hanusch, produk jurnalisme perjalanan seringkali disamakan dengan tulisan perjalanan. Padahal, keduanya merupakan produk yang berbeda. Jurnalis perjalanan memiliki peran yang lekat kaitannya dengan kegiatan jurnalistik, di mana jurnalis dituntut untuk menyampaikan fakta di lapangan tanpa menambah bumbu-bumbu fiksi (Hanusch, 2010). Detik.com dalam mempublikasikan berita Desa Sade tidak hanya mengandalkan para jurnalisnya, tetapi juga penulis lepas. Untuk itu, peneliti dapat melihat perbedaan produksi teks dari jurnalis dan penulis lepas, yang juga berkaitan dengan analisis wacana budaya Suku Sasak di detik.com dalam merepresentasikan tempat wisata Desa Sade.

Representasi budaya Suku Sasak yang dibangun oleh detik.com juga diduga terpengaruh oleh faktor internal dan eksternal yang tertera dalam teori hirarki pengaruh. Teori hirarki pengaruh merupakan teori tentang isi media dan faktor-faktor yang membentuknya (Krisdinanto, 2014). Isi pemberitaan dalam suatu media dipengaruhi oleh dua faktor, yaitu faktor eksternal dan internal (Krisdinanto, 2014). Gerakan ramah pariwisata yang diusung oleh pemerintah pada akhir 2018 lalu diduga menjadi faktor eksternal yang memengaruhi detik.com dalam memunculkan citra positif terkait Desa Sade.

Faktor yang mendukung pentingnya penelitian ini juga didasarkan pada kurangnya penelitian di bidang jurnalisme perjalanan. Tidak banyak penelitian terkait wisata yang berhubungan dengan jurnalisme perjalanan. Mengingat berita wisata merupakan bagian dari jurnalisme perjalanan, maka peneliti turut berkontribusi dalam bidang akademis, khusususnya bidang jurnalisme perjalanan dalam bentuk analisis wacana kritis. Peneliti tertarik untuk menganalisis berita wisata di detik.com yang produksi beritanya tidak hanya diproduksi oleh jurnalis, tetapi juga penulis lepas. Selain itu, peneliti juga belum menemukan penelitian serupa yang mengkaji teks berita Desa Sade, sehingga penelitian ini dapat menjadi kebaruan dalam bidang akademis.

Adapun penelitian yang berkaitan dengan jurnalisme perjalanan, yaitu penelitian yang dilakukan oleh Mita Anggraeni dan Muhametti Syas dengan judul "Representasi Pariwisata di Kabupaten Tojo Una-Una, Sulawesi Tengah pada Majalah Destinasi Indonesia". Kedua peneliti menggunakan metode analisis wacana semiotika sosial model M.A.K. Halliday untuk melihat representasi yang ditampilkan oleh majalah Destinasi Indonesia terkait pariwisata di Kabupaten Tojo Una-Una berdasarkan tiga aspek, yaitu pelibat wacana, posisi pelibat dan elemen sarana wacana. Berdasarkan hasil penelitian, majalah Destinasi Indonesia telah memenuhi unsur pariwisata yang terdapat di Kabupaten Tojo Una-Una. Pelibat wacana dalam majalah tersebut hanya menyertakan satu narasumber dalam setiap feature destinasi. Sementara posisi pelibat 
wacana digambarkan secara implisit. Kemudian, elemen sarana wacana yang digunakan dalam majalah tersebut yaitu menggunakan ragam bahasa sastra (Anggraeni \& Syas, 2019). Meskipun terdapat perbedaan metode penelitian, namun peneliti mengacu pada penelitian yang dilakukan oleh Anggraeni dan Syas untuk menerapkan konsep wacana yang diterapkan oleh detik.com dalam berita wisata.

Penelitian selanjutnya merupakan penelitian Syarifah Zulfatirahmi dengan judul "Representasi Eksotisme dalam Pemberitaan Destinasi Wisata Indonesia (Analisis Teks Majalah Travel Club Magazine dan DestinAsian Indonesia Edisi Juni - September 2017)". Syarifah Zulfatirahmi mencoba menganalisis wacana eksotisme dalam dua majalah wisata, yaitu DestinAsian dan Travel Club Magazine. Berdasarkan hasil penelitiannya, Zulfatirahmi menilai bahwa kedua majalah yang diteliti menggunakan wacana eksotisme sebagai bagian dari wacana poskolonial. Zulfatirahmi juga mengaitkan dengan konsep jurnalisme perjalanan yang disampaikan oleh Hanusch. Berdasarkan penelitiannya, Zulfatirahmi menilai kedua majalah tersebut belum memenuhi dimensi jurnalisme perjalanan yang disampaikan oleh Hanusch (Zulfatirahmi, 2018). Peneliti berpedoman pada penelitian yang dilakukan Zulfatirahmi mengingat terdapat persamaan dengan penelitian ini, seperti objek yang diteliti merupakan berita wisata yang menyangkut eksotisme dan menggunakan analisis wacana kritis model Norman Fairclough.

Penelitian lain terkait berita wisata juga dilalukan oleh Muharrik Thariquddien Fikri Amali dan Mursito dengan judul "Konstruksi Media Cetak Kompas dalam Berita Aktivitas Pariwisata Indonesia (Studi Analisis Wacana Terhadap Teks Berita Pariwisata Indonesia di Harian Umum Kompas Periode 2016)". Kedua peneliti menggunakan analisis wacana kritis model Teun A Van Djik untuk menganalisis berita terkait aktivitas pariwisata Indonesia. Hasil penelitian menunjukkan bahwa media yang diteliti menjabarkan upaya pemerintah dalam mengembangkan sektor pariwisata (Amali \& Mursito, 2016). Kompas juga menunjukkan ketertinggalan pariwisata Indonesia yang pemaparannya dibandingkan dengan pariwisata di negara lain. Meskipun sedikit berbeda dengan penelitian ini, namun peneliti berpedoman pada penelitian Amali dan Mursito untuk melihat penerapan paradigma kritis dalam menganalisis berita wisata.

Penelitian di bidang jurnalisme perjalanan juga disampaikan oleh Hanusch dengan judul "Representastions of Foreign Places Outside The News: An Analysis of Australian Newspaper Travel Sections". Hanusch meneliti enam surat kabar Australia yang menerbitkan artikel perjalanan dengan tujuan untuk mencari tahu bagaimana destinasi asing ditampilkan oleh surat kabar yang dianalisis. Hasil penelitian Hanusch menunjukkan bahwa keenam media yang diteliti kurang merepresentasikan budaya di dalam artikelnya. Para jurnalis yang menulis artikel lebih mengutamakan pengalaman pribadi dan mengabaikan representasi budaya (Hanusch, 2011). Berdasarkan penelitian Hanusch, peneliti dapat berpedoman untuk menganalisis portal detik. com dalam menyampaikan berita perjalanan sesuai dengan konsep jurnalisme perjalanan yang disampaikan oleh Hanusch.

\section{METODE}

Penelitian ini merupakan penelitian kualitatif dengan metode analisis wacana kritis model Norman Fairclough. Penelitian kualitatif pada hakikatnya adalah mengamati orang dalam lingkungannya, berinteraksi dengan mereka, berusaha memahami bahasa dan tafsiran mereka tentang dunia sekitarnya (Rukajat, 2018). Objek penelitian ini yaitu berita-berita Desa Sade yang dipilih peneliti untuk dianalisis menggunakan analisis wacana kritis. Empat berita yang dipilih oleh peneliti, yaitu: 
Tabel 1. Objek Penelitian

\begin{tabular}{|c|l|l|l|l|}
\hline No & \multicolumn{1}{|c|}{ Judul Berita } & Penulis & \multicolumn{1}{c|}{$\begin{array}{c}\text { Tanggal } \\
\text { Terbit }\end{array}$} & \multicolumn{1}{c|}{ Keterangan } \\
\hline 1 & $\begin{array}{l}\text { Tradisi-tradisi Super } \\
\text { Unik dari Desa Sade }\end{array}$ & $\begin{array}{l}\text { Hayyu } \\
\text { Zaakiyah }\end{array}$ & $\begin{array}{l}\text { Senin, 28 } \\
\text { Oktober 2019 }\end{array}$ & $\begin{array}{l}\text { Ditulis oleh D'Travelers dan } \\
\text { dipublikasikan dalam rubrik } \\
\text { detiktravel }\end{array}$ \\
\hline 2 & $\begin{array}{l}\text { Dengar Cerita Tradisi } \\
\text { Kawin Culik Orang } \\
\text { Sasak, Mufidah Kalla: } \\
\text { Unik Sekali }\end{array}$ & Eva Safitri & $\begin{array}{l}\text { Rabu, 14 } \\
\text { Agustus 2019 }\end{array}$ & $\begin{array}{l}\text { Ditulis oleh wartawan detik.com dan } \\
\text { dipublikasikan dalam rubrik detiknews }\end{array}$ \\
\hline 3 & $\begin{array}{l}\text { Melihat Lebih Dekat } \\
\text { Kehidupan Suku Sasak } \\
\text { di Desa Sade Lombok } \\
\text { Tengah }\end{array}$ & $\begin{array}{l}\text { Tim } \\
\text { Reportase } \\
\text { Trans TV }\end{array}$ & $\begin{array}{l}\text { Selasa, 26 } \\
\text { Februari 2019 }\end{array}$ & $\begin{array}{l}\text { Dipublikasikan dalam rubrik } \\
\text { detiktravel yang merupakan unggahan } \\
\text { ulang dari hasil reportase Trans TV }\end{array}$ \\
\hline 4 & $\begin{array}{l}\text { Tradisi Adat Desa Sade } \\
\text { yang Bikin Tercengang }\end{array}$ & $\begin{array}{l}\text { Ni Putu } \\
\text { Dian Ayu }\end{array}$ & $\begin{array}{l}\text { Minggu, 24 } \\
\text { Februari 2019 }\end{array}$ & $\begin{array}{l}\text { Ditulis oleh D'Travelers dan } \\
\text { dipublikasikan dalam rubrik } \\
\text { detiktravel }\end{array}$ \\
\hline
\end{tabular}

Sumber: Olahan Peneliti, 2020

Keempat berita dianalisis menggunakan analisis wacana kritis model Norman Fairclough. Terdapat tiga level yang digunakan Fairclough dalam analisis wacana kritis, yaitu level teks, level praktik wacana dan level sosiokultural (Fairclough, 1995). Berikut gambar yang menunjukkan penerapan analisis wacana kritis model Norman Fairclough dalam penelitian ini:

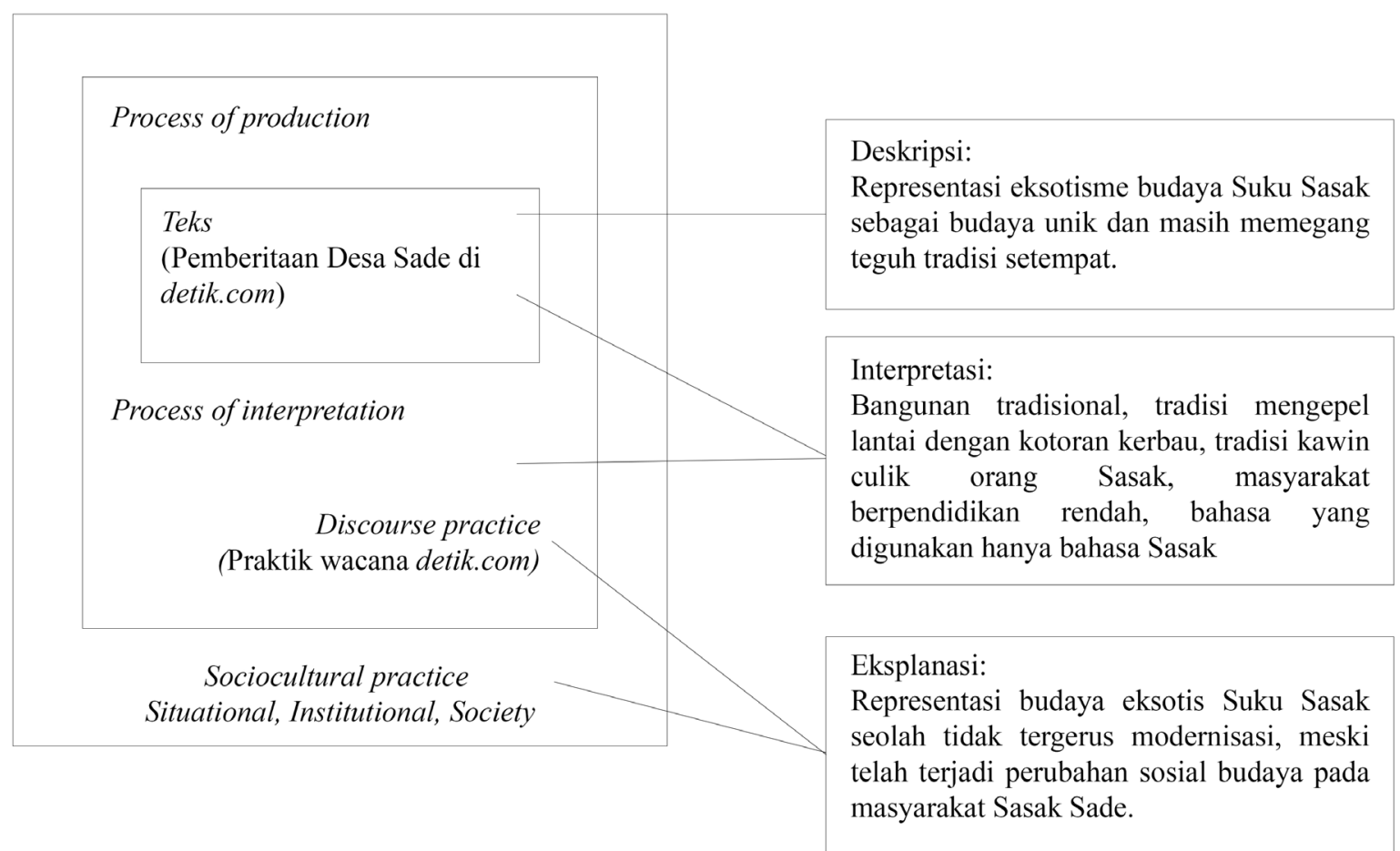

Gambar 1. Penerapan Analisis Wacana Kritis Model Norman Fairclough terhadap Pemberitaan Desa Sade di Detik.com

Sumber: Olahan Peneliti, 2020

Pada analisis level teks, peneliti menggunakan lima alat yang disebutkan oleh Fairclough, yaitu kendali interaksional, etos, metafora, kata-kata dan tata bahasa. Peneliti menggunakan kendali interaksional untuk melihat siapa yang mengatur agenda percakapan dan mengendalikan 
pesan yang disampaikan dalam teks yang dianalisis. Etos digunakan untuk melihat identitas sosial yang ditampilkan oleh detik.com dalam teks berita Desa Sade. Sementara metafora, katakata dan tata bahasa digunakan peneliti untuk melihat bagaimana representasi budaya eksotis yang muncul dalam pemberitaan Desa Sade pada portal berita detik.com.

Pada aspek tata bahasa, Fairclough menggunakan dua aspek untuk menganalisis teks, yaitu transivitas dan modalitas. Transivitas digunakan untuk melihat bagaimana peristiwa terhubung atau tidak terhubung dengan subjek dan objek. Dalam menganalisis transivitas, peneliti dapat melihat penggunaan kalimat aktif atau pasif yang digunakan detik.com dalam merepresentasikan budaya eksotis di Desa Sade. Sementara pada aspek modalitas, peneliti dapat melihat tingkat afinitas pelibat yang dimunculkan oleh detik.com. Pemilihan modalitas yang digunakan oleh detik.com dalam teksnya akan dibedakan sesuai dengan tipe modalitas yang disebutkan oleh Jorgersen, yaitu kebenaran (truth), izin (permission) dan modalitas yang dieskpresikan berdasarkan intonasi (by hedges) (Jorgensen, 2012).

Kedua, level praktik wacana. Level Praktik Wacana dalam analisis wacana kritis model Norman Fairclough membahas tentang proses produksi dan konsumsi teks (Fairclough, 1995). Untuk mengetahui proses produksi dan konsumsi dalam pemberitaan Desa Sade di detik.com, peneliti melakukan wawancara dengan Redaktur Pelaksana detiknews dan Redaktur Pelaksana detiktravel terkait alur produksi yang dijalankan oleh detik.com dalam memproduksi berita Desa Sade yang merepresentasikan budaya Suku Sasak sebagai budaya asli atau belum tergerus modernisasi.

Ketiga, level praktik sosiokultural. Menurut Fairclough, praktik sosiokultural merupakan hubungan antara praktik wacana dengan urutan wacana untuk dieksplorasi (Jorgensen, 2012). Pada level ini, peneliti menganalisis berdasarkan tiga tingkatan, yakni situasi, institusional dan sosial. Pada aspek situasional, peneliti menganalisis bagaimana teks wacana budaya Suku Sasak dalam berita Desa Sade dipengaruhi oleh keadaan atau situasi yang terjadi ketika teks itu dibuat. Pada aspek institusional, peneliti melihat bagaimana detik.com memengaruhi teks yang diproduksi. Sementara pada aspek sosial, peneliti menganalisis aspek makro yang memengaruhi produksi berita wacana budaya 65 Suku Sasak di Desa Sade yang merujuk pada perubahan sosial yang terjadi pada masyarakat Sade.

Pada penelitian ini, peneliti juga melakukan wawancara terhadap subjek penelitian. Wawancara dilakukan secara virtual untuk menggali data terkait proses produksi berita yang dilakukan oleh detik.com. Subjek yang diwawancarai yaitu Redaktur Pelaksana detiknews, Fajar Pratama, dan Redaktur Pelaksana detiktravel, Dadan Kuswaraharja. Kedua Redaktur Pelaksana detik.com diwawancarai mengingat tiga berita yang dipilih merupakan bagian detiktravel dan satu berita merupakan bagian detiknews. Proses wawancara dilakukan secara virtual karena keterbatasan peneliti saat pandemi COVID-19.

Setelah melakukan analisis wacana kritis, peneliti menggunakan analisis Miles dan Huberman dalam menganalisis data. Pertama, peneliti mengumpulkan data lalu mereduksi data penelitian dari awal hingga akhir penelitian. Reduksi dilakukan dengan mengelompokkan data yang diperlukan dan yang tidak diperlukan. Kedua, peneliti melakukan display data untuk memudahkan peneliti dalam melakukan analisis. Ketiga, peneliti mengambil kesimpulan berdasarkan hasil penelitian yang telah peneliti kelompokkan. Peneliti juga melakukan verifikasi data dengan proses triangulasi untuk mengecek kebenaran dari hasil penelitian yang telah diperoleh.

\section{HASIL DAN PEMBAHASAN}

Wacana budaya Suku Sasak direpresentasikan detik.com sebagai budaya unik yang masih

Wacana Budaya Suku Sasak di Desa Sade dalam Detik.com (Regita Nada Yalatama, Nuryah Asri Sjafirah, dan Rinda Aunillah) 
dipertahankan oleh masyarakat Desa Sade. Representasi demikian cukup berbeda dengan dua penelitian akademis terkait perubahan budaya Desa Sade. Untuk menganalisis secara lebih mendalam, peneliti menganalisis berdasarkan tiga level yang disebutkan oleh Norman Fairclough, meliputi level teks, level praktik wacana dan level sosiokultural. Berikut ringkasan hasil penelitian yang dikaji berdasarkan tiga level:

Tabel 2. Hasil Penelitian berdasarkan Model Norman Fairclough

\begin{tabular}{|c|l|l|l|}
\hline No & \multicolumn{1}{|c|}{ Level Analisis } & \multicolumn{1}{c|}{ Aspek yang Dianalisis } & \multicolumn{1}{c|}{ Hasil Penelitian } \\
\hline 1 & Level Teks & $\begin{array}{l}\text { Kendali interaksional, etos, } \\
\text { kosakata, metafora dan tata } \\
\text { bahasa }\end{array}$ & $\begin{array}{l}\text { Budaya Suku Sasak } \\
\text { direpresentasikan sebagai bagian } \\
\text { dari wacana poskolonial karena } \\
\text { dianggap 'unik' }\end{array}$ \\
\hline 2 & $\begin{array}{l}\text { Level Praktik } \\
\text { Wacana }\end{array}$ & $\begin{array}{l}\text { Intertekstualitas } \\
\text { (Intertekstualitas terwujud dan } \\
\text { interdiskursivitas) }\end{array}$ & $\begin{array}{l}\text { Praktik wacana ditujukan untuk } \\
\text { memajukan budaya Indonesia }\end{array}$ \\
\hline 3 & Level Sosiokultural & $\begin{array}{l}\text { Realitas sosiokultural } \\
\text { (situasional, institusional dan } \\
\text { sosial) }\end{array}$ & $\begin{array}{l}\text { Aspek makro memengaruhi detik. } \\
\text { com dalam merepresentasikan } \\
\text { budaya Suku Sasak di Desa Sade }\end{array}$ \\
\hline
\end{tabular}

Sumber: Olahan Peneliti, 2020

Pertama, Level Teks. Pemberitaan Desa Sade dalam portal berita detik.com tidak pernah lepas dari pembahasan terkait budaya Suku Sasak. Informasi budaya Suku Sasak yang dianggap masih kental di Desa Sade menjadi wacana yang dominan dalam pemberitaan Desa Sade di detik.com. Peneliti menganalisis teks pemberitaan Desa Sade di detik.com dengan menggunakan lima alat yang disarankan oleh Fairclough dalam analisis wacana kritis, yaitu kendali interaksional, etos, kata-kata, metafora dan tata bahasa.

Kendali interaksional digunakan peneliti untuk melihat siapa yang mengatur agenda percakapan dan mengendalikan pesan yang disampaikan dalam teks yang dianalisis. Kendali interaksional yang ditunjukkan oleh detik.com dalam pemberitaan Desa Sade pada umumnya dikendalikan oleh penulis dan narasumber yang terlibat dalam teks pemberitaan. Pada berita pertama berjudul "Tradisi-tradisi Super Unik dari Desa Sade", agenda percakapan dikendalikan oleh Hayyu Zaakiyah sebagai penulis. Teks yang ditulis oleh Hayyu Zaakiyah merupakan representasi dari budaya Suku Sasak. Penggunaan kata 'Anda' dalam teks yang dibuat oleh Hayyu Zaakiyah juga menunjukkan adanya relasi antara Zaakiyah dengan pembaca, di mana Zaakiyah menempatkan diri sebagai pemberi informasi kepada para pembaca yang ingin mengetahui Desa Sade.

Pada berita kedua berjudul "Dengar Cerita Tradisi Kawin Culik Orang Sasak, Mufidah Kalla: Unik Sekali", agenda percakapan dan kendali pesan berada di tangan Talep dan Mufidah Kalla sebagai narasumber. Berita yang ditulis oleh Eva Safitri tersebut merupakan berita dengan format straight news. Terdapat kutipan langsung maupun tidak langsung dalam teks yang dibangun oleh Eva berdasarkan informasi dari kedua narasumber. Wacana yang diaktifkan oleh Eva dalam teks tersebut mengarah pada representasi budaya Suku Sasak yang merupakan penjelasan dari para narasumber, yakni Talep dan Mufidah Kalla. Maka, peneliti menilai kendali interaksional pada berita kedua dikendalikan oleh narasumber.

Sementara pada berita ketiga berjudul "Melihat Lebih Dekat Kehidupan Suku Sasak di Desa Sade Lombok Tengah", agenda percakapan dan kendali pesan berada di tim Reportase Trans $T V$ dan warga setempat. Tim reportase Trans $T V$ mengendalikan pesan yang ingin disampaikan kepada khalayak dengan mengatur scene terkait budaya yang ditunjukkan 
kepada khalayak. Perwakilan tim reportase yang muncul dalam video yaitu pembawa acara, Linda Wahhyuni, yang terlihat mengendalikan pesan dari awal hingga akhir video. Sementara pemunculan warga setempat dalam scene berita tersebut juga turut mengendalikan pesan terkait budaya Suku Sasak.

Tidak berbeda dari analisis berita pertama, kendali interaksional pada berita keempat berjudul "Tradisi Adat Desa Sade yang Bikin Tercengang" berada di tangan penulisnya, yakni Ni Putu Dian Antalina. Ni Putu Dian mengendalikan representasi budaya Suku Sasak dengan memaparkan pengalamannya ketika mengunjungi Desa Sade. Secara tersirat, peneliti juga melihat agenda percakapan turut dikendalikan oleh pemandu wisata yang menemani Ni Putu Dian saat mengunjungi Desa Sade. Sayangnya, tidak ada kutipan pemandu wisata yang menandakan keterlibatan dalam mengatur agenda percakapan. Nampaknya, bentuk artikel yang dibuat oleh para penulis lepas, khususnya Hayyu Zaakiyah dan Ni Putu Dian, dibuat berdasarkan pengalaman pribadi, sehingga kendali pesan tidak berasal dari narasumber.

Selanjutnya, peneliti menganalisis teks berdasarkan aspek etos, yang juga berhubungan dengan aspek kata-kata, metafora dan tata bahasa. Etos merupakan alat untuk menganalisis teks yang digunakan untuk melihat bagaimana identitas sosial dikonstruksikan melalui bahasa dan aspek-aspek yang ada dalam teks (Jorgensen, 2012). Etos digunakan untuk melihat identitas sosial yang ditampilkan oleh detik.com dalam teks berita Desa Sade. Pada berita pertama, Hayyu Zaakiyah mengidentitaskan Desa Sade sebagai dusun yang budayanya masih terjaga, murni atau belum tergerus modernisasi. Identitas demikian digambarkan melalui kata-kata bermakna gramatikal dan leksikal. Identitas Desa Sade berdasarkan makna gramatikal dibangun dengan kata: masih memegang teguh, masih menjaga dan masih mempertahankan.

Kata memegang memiliki makna sebagai representasi budaya Suku Sasak yang masih dianut oleh warga Desa Sade. Sedangkan kata teguh berasal dari bahasa Minangkabau, yakni gigih, yang memiliki arti keras hati; tetap terguh pada kemauannya/keinginannya (Hanum, 2019). Kata menjaga berasal dari bahasa Jawa, yaitu lestari atau melestarikan, memiliki arti memelihara/menjaga sesuatu agar tidak rusak (Hanum, 2019). Sementara kata memegang dan mempertahankan yang digunakan oleh Zaakiyah memiliki makna yang sama dengan kata menjaga. Artinya, detik.com dalam berita yang ditulis Hayyu Zaakiyah ingin menekankan identitas Desa Sade sebagai desa yang masih mempertahankan adat istiadat setempat.

Detik.com merepresentasikan budaya Suku Sasak dengan makna gramatikal juga muncul dalam teks berita ketiga. Tim Reportase Trans TV menggunakan kata mengabaikan dan mempertahankan untuk merepresentasikan budaya Suku Sasak di Desa Sade. Kata mengabaikan merupakan kata dasar 'abai' yang disertai dengan imbuhan me- dan -an. Abai memiliki arti: tidak dipedulikan; tidak dikerjakan baik-baik; tidak dipentingkan (Aksan, 2017). Sementara kata mempertahankan memiliki arti yang sama dengan analisis berita pertama. Artinya, pada berita ketiga juga detik.com mencoba untuk merepresentasikan budaya Suku Sasak sebagai budaya yang masih dipertahankan oleh masyarakat setempat. Selain itu, kata memegang teguh dalam analisis berita pertama juga muncul kembali dalam berita keempat. Sebagaimana telah disebutkan, memegang teguh menandakan bahwa masyarakat Sade direpresentasikan sebagai masyarakat yang masih menganut budaya setempat.

Selain kata bermakna gramatikal, representasi budaya Suku Sasak yang diidentitaskan sebagai budaya eksotis, yang belum tergerus modernisasi, juga dibangun dengan kata bermakna leksikal. Kata bermakna leksikal yang digunakan oleh detik.com dalam merepresentasikan budaya Suku Sasak, yaitu unik, jarang, aneh, asli, dan kental. Kata unik muncul dalam berita pertama dan kedua. Kata unik memiliki arti: tersendiri dalam bentuk atau jenisnya; lain daripada yang lain; tidak ada persamaan dengan yang lain (Aksan, 2017). 
Sementara kata jarang dan aneh muncul dalam berita pertama. Kata jarang berasal dari bahasa Jawa, yakni langka, artinya jarang ada (Hanum, 2019). Sedangkan kata aneh menurut Kamus Besar Bahasa Indonesia daring, yaitu tidak seperti yang kita lihat atau dengar. Berdasarkan makna dari kedua kata tersebut, dapat dinilai bahwa Zaakiyah merepresentasikan budaya Suku Sasak di Desa Sade sebagai budaya yang berbeda. Dengan kata lain, budaya Suku Sasak dianggap 'asing', yang merujuk pada wacana eksotisme.

Selanjutnya, peneliti melihat detik.com menggunakan kata asli dalam mengidentitaskan budaya Suku Sasak Sade. Kata asli muncul dalam berita kedua. Kata asli dalam KBBI daring memiliki arti tidak ada campurannya; tulen; murni. Dengan arti tersebut, Eva Safitri mencoba untuk merepresentasikan budaya Suku Sasak sebagai budaya yang masih murni dari para leluhurnya atau tidak ada campuran yang memengaruhi budaya Suku Sasak.

Sementara itu, kata kental muncul dalam berita keempat. Kata kental dalam KBBI daring memiliki arti antara cair dan keras. Penggunaan kata kental yang semula ditujukan untuk menunjuk susu atau cairan, kini digunakan untuk menunjukkan budaya. Penggunaan kata 'sangat kental' pada kalimat (3) memiliki maksud bahwa budaya Suku Sasak di Desa Sade yang berasal dari para leluhurnya masih murni dijalankan oleh warga setempat.

Representasi Desa Sade yang diidentitaskan sebagai dusun yang memiliki budaya yang kental juga dibangun melalui metafora. Pada berita pertama, metafora yang digunakan adalah: mata Anda akan disajikan \& menghabiskan masa tua. Zaakiyah menggunakan kata 'disajikan' untuk mengonstruksi realitas budaya Suku Sasak di Desa Sade. Jenis metafora yang digunakan Zaakiyah, yaitu metafora sinestesis, di mana sajian yang semula digunakan untuk makanan beralih pada penunjukkan budaya di Desa Sade. 'Menghabiskan masa tua' juga termasuk dalam jenis metafora sinestesis, di mana "masa tua" atau usia dianggap sebagai suatu hal yang dapat dihabiskan. Penggunaan metafora tersebut digunakan Zaakiyah untuk menggambarkan sebuah tempat (Bale) yang digunakan orang tua Sade sebagai tempat untuk menggunakan sisa waktu dalam hidupnya hingga mereka meninggal.

Pada berita kedua, metafora yang digunakan yaitu disambut tari Peresean, berlaga seperti adu silat, dan menolak bala. 'Disambut tari Peresean' merupakan metafora antropomorfik, di mana tarian seolah bisa menyambut seperti yang dilakukan manusia. Metafora 'berlaga seperti adu silat' merupakan perumpamaan yang menggunakan kata 'seperti'. Dalam hal ini, Eva mengonstruksi tari Peresean sebagai tarian yang mirip dengan adu silat untuk mempermudah pembaca mendapatkan gambaran terkait tarian yang dimunculkan dalam teks. Sementara itu, 'menolak bala' merupakan istilah yang memiliki maksud untuk menghindari sesuatu yang dipakai untuk menolak penyakit (Aksan, 2017).

Pada berita ketiga, metafora yang digunakan yaitu waktu seolah berputar mundur dan berlindung dari panas dan hujan. Penggunaan istilah 'waktu seolah berputar mundur' merupakan metafora antropomorfik, di mana waktu diumpamakan sebagai benda bernyawa yang bisa bergerak mundur. Maksud dari metafora tersebut menyebutkan bahwa tim reportase Trans $T V$ ingin menunjukkan bahwa Desa Sade merupakan desa yang belum mengalami modernisasi. Sementara 'berlindung dari panas dan hujan' merupakan metafora sinestesis, di mana makna berlindung dari panas dan hujan yang bisa saja ditujukan untuk fungsi payung, beralih pada fungsi rumah.

Sementara pada berita keempat, metafora yang muncul yaitu berlangsung selama ratusan tahun, tercengang, dan masih sangat kental. Penggunaan kata 'berlangsung selama ratusan tahun' dan 'tercengang' merupakan kata-kata yang sedikit dilebih-lebihkan oleh Ni Putu Dian untuk menggambarkan budaya Suku Sasak sebagai budaya eksotis yang telah ada sejak jaman nenek moyang dan budaya yang sangat 'luar biasa'. Sementara 'masih sangat 
kental' merupakan metafora sinestesis, di mana kata kental yang biasanya digunakan untuk menunjukkan benda antara cair dan padat, ditunjukkan untuk merepresentasikan budaya Suku Sasak Sade.

Selanjutnya, pada aspek tata bahasa, peneliti menganalisis transivitas dan modalitas dalam teks berita yang dianalisis. Pada berita pertama, transivitas yang banyak digunakan oleh Hayyu Zaakiyah yaitu transivitas proses material dan verbal. Contoh proses material ditunjukkan dengan menggunakan kata mengepel, memakai, menikahi, dan menculik. Proses material digunakan untuk merepresentasikan aksi yang dilakukan masyarakat Sade dalam menerapkan budaya Suku Sasak. Sementara contoh transivitas proses verbal ditunjukkan dengan menggunakan kata menyebutnya, meminta izin, menghubungi dan memberitahu. Pemilihan kata dengan proses verbal digunakan untuk merepresentasikan aksi dalam bentuk verbal yang dilakukan masyarakat Sade untuk menerapkan budaya Suku Sasak. Artinya, transivitas yang digunakan oleh Zaakiyah bertujuan untuk merepresentasikan budaya Suku Sasak. Sementara itu, modalitas yang ditunjukkan dalam berita Zaakiyah lebih dominan menggunakan modalitas subjektif yang membuat otoritas fakta terkait representasi budaya eksotis pada Suku Sasak Sade menjadi tidak kuat.

Pada berita kedua, transivitas yang banyak digunakan oleh Eva Safitri yaitu transivitas proses verbal. Terdapat kutipan langsung dan tidak langsung dari narasumber yang membuat Eva menggunakan proses verbal dalam merepresentasikan budaya Suku Sasak. Transivitas proses verbal yang digunakan oleh Eva, yaitu menyebut, ujar, kata, memperkenalkan, ucap, tutur, menjelaskan dan mengatakan. Sementara modalitas yang digunakan oleh Eva didominasi oleh modalitas objektif yang membuat otoritas fakta yang disampaikannya mengenai eksotisme budaya Suku Sasak menjadi kuat.

Pada berita ketiga, transivitas yang digunakan oleh tim Reportase Trans TV lebih banyak menggunakan proses material untuk menggambarkan budaya Suku Sasak di Desa Sade. Proses material ditunjukkan dengan menggunakan kata mengabaikan, mempertahankan, digunakan, membersihkan, mengepel, mengoleskan, mengeratkan, menghilangkan dan menjaga. Katakata bermakna gramatikal tersebut merupakan proses material yang merepresentasikan aksi warga Sade dalam menjalankan budaya Suku Sasak dari para leluhurnya. Sementara dalam aspek modalitas, tim reportase Trans $T V$ tidak terlalu banyak menggunakan modalitas dalam videonya.

Sementara pada berita keempat, transivitas yang digunakan oleh Ni Putu Dian, yaitu transivitas proses material dan verbal. Transivitas dengan proses material ditunjukkan dengan menggunakan kata menculik, menenun, dan dipel untuk menunjukkan budaya kawin culik, menenun dan mengepel lantai dengan kotoran kerbau. Sedangkan transivitas proses verbal digunakan dengan menggunakan kata mengatakan dan memberitahukan untuk menggambarkan tradisi kawin culik Suku Sasak. Sementara modalitas yang digunakan mencakup modalitas objektif dan subjektif.

Berdasarkan analisis teks dalam aspek tata bahasa, khusususnya transivitas, peneliti melihat detik.com menggunakan kalimat aktif dalam membangun berita Desa Sade. Artinya, terdapat hegemoni dalam pemberitaan yang dibuat oleh detik.com terkait Desa Sade yang dianggap unik dan kental akan budaya yang belum tergerus modernisasi. Subjek dan objek yang ditampilkan dalam teks memiliki keterkaitan, karena detik.com tidak menyembunyikan aktor yang terlibat. Sementara modalitas yang digunakan merupakan modalitas objektif dan subjektif. Modalitas objektif menunjukkan derajat afinitas yang tinggi atas fakta yang disampaikan, seperti pada berita kedua dan ketiga. Sementara modalitas subjektif cenderung digunakan oleh para penulis lepas yang menandakan derajat afinitas rendah atas fakta yang 
disampaikan, seperti berita pertama dan keempat.

Analisis teks yang telah diuraikan menunjukkan bahwa detik.com merepresentasikan wacana budaya Suku Sasak di Desa Sade sebagai wacana poskolonial yang dipopulerkan oleh Edward Said. Representasi Suku Sasak yang dianggap masih 'murni' atau 'asli' merujuk pada pengertian orient. Orient merupakan penemuan bangsa Eropa yang mengarah pada tempat romansa, makhluk eksotis dan kenangan atau pemandangan yang menghantui, dan pengalaman berharga (Said, 1979). Detik.com merepresentasikan budaya Suku Sasak sebagai budaya yang eksotis, sehingga peneliti menilai bahwa detik.com menggunakan wacana poskolonial dalam merepresentasikan budaya Suku Sasak Sade yang dianggap unik.

Kedua, Level Praktik Wacana. Pada level praktik wacana, peneliti melihat intertekstualitas yang merupakan kondisi di mana sebuah komunikasi (teks) dibentuk berdasarkan teks sebelumnya (Jorgensen, 2012). Pada tahap ini, intertekstualitas digunakan untuk melihat bagaimana penulis berita Desa Sade memproduksi berita dengan melihat suara-suara yang muncul dalam teks. Intertekstualitas yang dianalisis meliputi intertekstualitas terwujud dan interdiskursivitas.

Dari keempat berita yang telah dianalisis, intertekstualitas terwujud muncul dalam berita kedua berjudul "Dengar Cerita Tradisi Culik Orang Sasak. Mufidah Kalla: Unik Sekali" oleh Eva Safitri dan berita ketiga "Melihat Lebih Dekat Kehidupan Suku Sasak di Desa Sade Lombok Tengah" oleh Reportase Trans TV. Intertekstualitas terwujud ditampilkan Eva melalui kutipan langsung dan tidak langsung yang muncul dalam teks. Pernyataan yang diambil dari narasumber menjadi bahan untuk Eva dalam merepresentasikan budaya Suku Sasak Sade. Pun dengan berita yang dibuat Trans $T V$ yang memunculkan scene warga setempat yang turut membangun representasi budaya Suku Sasak di Desa Sade.

Sementara pada berita pertama dan keempat, peneliti tidak menemukan intertekstualitas terwujud. Peneliti menilai bahwa teks yang dibuat oleh Hayyu Zaakiyah dan Ni Putu Dian merupakan teks yang bersifat subjektif berdasarkan pengalaman pribadi, sehingga tidak memunculkan kutipan narasumber. Hal demikian membuat otoritas fakta yang disampaikan cenderung lemah atau tidak kuat.

Selain kutipan langsung, peneliti juga melihat kecenderungan teks dari keempat berita yang dianalisis. Detik.com cenderung merepresentasikan budaya Suku Sasak sebagai budaya unik, yang merujuk pada wacana eksotisme. Selain kata unik, berita yang dipublikasikan oleh detik.com merepresentasikan budaya Suku Sasak dengan kata asli, memegang teguh, mempertahankan dan menjaga. Kata-kata tersebut menunjukkan bahwa detik.com ingin merepresentasikan budaya Suku Sasak sebagai budaya yang masih asli. Penegasan budaya yang dinilai masih asli juga memiliki relasi dengan foto-foto yang ditampilkan. Foto yang ditampilkan detik.com merepresentasikan eksotisme budaya Suku Sasak secara visual. Berikut beberapa foto yang ditampilkan oleh detik.com dalam merepresentasikan budaya Suku Sasak di Desa Sade:

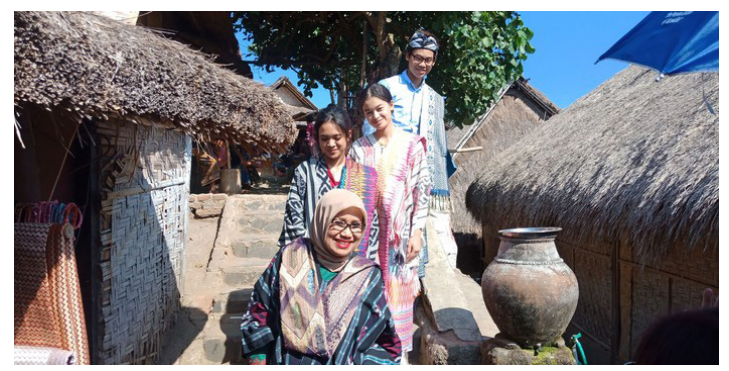

Gambar 2. Latar Foto bangunan tradisional yang ditampilkan detik.com Sumber: (Safitri, 2019)

Wacana Budaya Suku Sasak di Desa Sade dalam Detik.com (Regita Nada Yalatama, Nuryah Asri Sjafirah, dan Rinda Aunillah) 


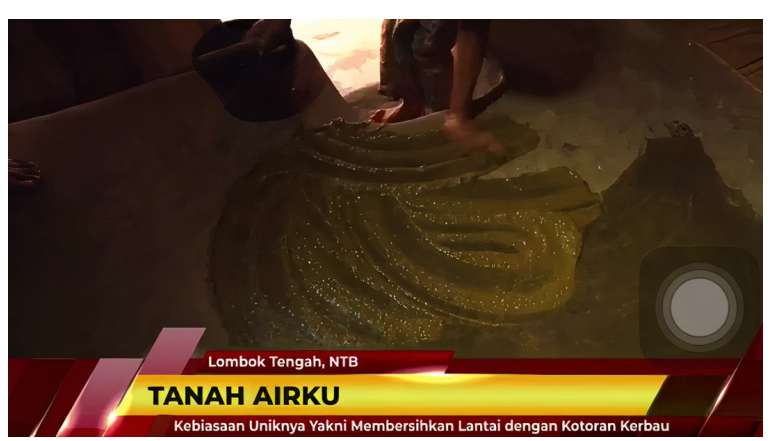

Gambar 3. Tradisi mengepel lantai dengan kotoran kerbau yang ditampilkan detik.com Sumber: (Reportase Trans TV, 2019)

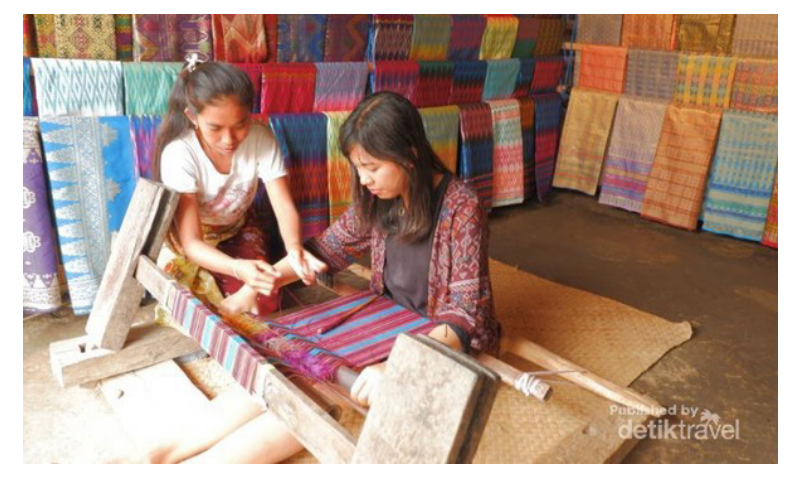

Gambar 4. Tradisi menenun Suku Sasak di Desa Sade yang ditampilkan oleh detik.com Sumber: (Antalina, 2019)

Sementara pada aspek interdiskursivitas, peneliti melihat genre, tipe aktivitas, gaya penulisan dan wacana dalam sebuah teks. Dari keempat berita yang telah dianalisis, peneliti melihat wacana yang ditampilkan dalam teks mengarah pada wacana yang bersifat menghibur dan bertujuan untuk mempromosikan tempat wisata Desa Sade. Keempat berita yang dianalisis mencoba melakukan persuasi terhadap pembaca agar mau mengunjungi Desa Sade. Hal demikian merepresentasikan peran detik.com sebagai media yang memiliki peran menghibur, mengedukasi dan menyampaikan pesan terkait budaya Suku Sasak di Desa Sade.

Berdasarkan wawancara dengan Redatur Pelaksana detiktravel, Dadan Kuswaraharja, menyampaikan bahwa tujuan artikel detiktravel, yaitu agar wisata Indonesia dapat lebih harum dan terkenal di dunia. Artinya, peran 'mempromosikan' Desa Sade menjadi bagian yang dipertimbangkan oleh detik.com. Selain itu, Desa Sade juga dianggap sebagai desa yang menarik karena merupakan salah satu daerah di Indonesia yang masih menerapkan pola-pola tradisional, mulai dari menenun sampai aspek lainnya.

Tidak jauh berbeda denga hasil wawancara bersama Redaktur Pelaksana detiktravel, Redaktur Pelaksana detiknews, Fajar juga menyampaikan alasan publikasi berita Mufidah Kalla. Menurut Fajar, pemberitaan Desa Sade dianggap penting untuk dipublikasikan kepada khalayak karena detik.com memiliki peran untuk memajukan budaya. Saat ini, di Indonesia banyak diterpa budaya popular. Perlu ada penjelasan budaya setempat yang sifatnya tidak terpotong-potong, maka detik.com memunculkan informasi terkait Desa Sade.

Berdasarkan penggalan wawancara dari kedua Redaktur Pelaksana detik.com, peneliti menilai bahwa detik.com berperan mempromosikan wisata Desa Sade agar dikenal oleh dunia dengan memunculkan budaya Suku Sasak yang dianggap sebagai budaya yang unik. Masyarakat diberi pemahaman terkait Suku Sasak yang dinilai belum tergerus modernisasi, sehingga 
memiliki keunikan yang perlu diketahui oleh masyarakat agar tertarik untuk mengunjungi Desa Sade. Selain itu, Fajar selaku Redaktur Pelaksana detiknews juga menambahkan bahwa publikasi berita Desa Sade bertujuan untuk mempertahankan kebudayaan di Indonesia. Menurut Fajar, Suku Sasak merupakan budaya yang menarik. Sebagai output-nya mereka memiliki kerajinan. Maka, budaya yang demikian perlu dipublikasikan secara terus-menerus agar tidak punah. Berdasarkan pernyataan Fajar, maka peneliti menilai bahwa peran lain yang dipegang oleh detik.com yaitu edukasi. Artinya, detik.com merasa bertanggung jawab untuk mempublikasikan budaya Suku Sasak Sade untuk memberikan pemahaman bagi masyarakat Indonesia terkait adanya budaya unik yang perlu dijaga dan dilestarikan agar tidak punah.

Ketiga, Level Praktik Sosiokultural. Pada bagian ini, peneliti melihat realitas sosiokultural yang berhubungan dengan praktik sosial yang membentuk teks pemberitaan Desa Sade oleh detik.com, meliputi situasional, institusional dan sosial. Pada aspek situasional, peneliti menilai representasi budaya Suku Sasak dipengaruhi oleh gerakan ramah pariwisata yang diusung oleh Kementerian Pariwisata pada akhir 2018. Situasi di mana media dihimbau untuk memunculkan berita positif terkait wisata agar dapat menarik perhatian pengunjung, menjadi faktor yang memengaruhi detik.com dalam merepresentasikan sisi positif dari Desa Sade.

Pada aspek institusional, tim redaksi detik.com juga turut memengaruhi publikasi berita Desa Sade. Kebijakan dan ketentuan yang ditetapkan detik.com memengaruhi berita yang dibangun oleh para penulisnya. Pada berita berjudul "Dengar Cerita Tradisi Kawin Culik Orang Sasak, Mufidah Kalla: Unik Sekali” oleh Eva Safitri, Redaktur Pelaksana detiknews mengatakan bahwa saat itu tim redaksi menerima rundown Mufidah Kalla yang sedang memiliki kegiatan di Desa Sade. Detik.com memiliki porsi pemberitaan bagi pejabat, termasuk Mufidah Kalla. Maka, tim redaksi memutuskan untuk meliput kegiatan Mufidah Kalla di Desa Sade.

Sementara pada aspek sosial, stigma Desa Sade yang dikenal sebagai wisata budaya telah melekat, sehingga perubahan budaya akibat modernisasi seringkali diabaikan. Penelitian yang dilakukan oleh Sari dan Nugroho berjudul "Dampak Sosial Budaya Pengembangan Dusun Sade sebagai Dusun Wisata di Kabupaten Lombok Tengah" yang mengungkapkan perubahan sosial budaya di Desa Sade tidak disampaikan oleh detik.com. Sari dan Nugroho mengungkapkan adanya perubahan dalam mata pencaharian, sistem organisasi dan bahasa (Sari \& Nugroho, 2018).

Penelitian lain dilakukan oleh Agus Sukandar dengan judul penelitian "Menggagas Pelestarian Permukiman Tradisional Dusun Sade sebagai Lansekap Budaya yang Mampu Mengantisipasi Kebutuhan Penghuninya". Menurutnya, Desa Sade telah mengalami perubahan sosial budaya. Perubahan terjadi pada aspek tata kehidupan, tata lingkungan, tata hijau, bentuk bangunan, dan penggunaan material (Sukandar, 2017). Meski sudah terdapat penelitian yang menjelaskan perubahan budaya di Desa Sade, nampaknya detik.com luput menampilkan perubahan akibat modernisasi dan lebih mengedepankan wacana eksotisme yang dimiliki oleh Desa Sade.

Berkaitan dengan praktik wacana dan sosiokultural, tentunya representasi Desa Sade sebagai desa yang kental akan budaya dipengaruhi oleh faktor internal dan eksternal. Faktor internal dan eksternal dibahas dalam teori Hirarki Pengaruh oleh Shoemaker \& Reese. Sebagaimana telah diulas dalam analisis wacana kritis, faktor internal, seperti individu pekerja detik.com, rutinitas, organisasi dan ideologi detik.com telah memengaruhi produksi berita Desa Sade. Detik.com yang merasa berperan dan bertanggung jawab untuk memajukan budaya Indonesia, membawa pengaruh terhadap representasi sisi positif dari Desa Sade. Sisi positif diulas dengan memunculkan Desa Sade sebagai desa unik yang 'harus' dikunjungi oleh pembaca. 
Sementara faktor luar sebagaimana yang telah disebutkan dalam praktik sosiokultural, berasal dari kebijakan pemerintah dalam menerapkan gerakan ramah pariwisata dan stigma budaya yang telah melekat di Desa Sade. Redaktur Pelaksana detiktravel juga menyatakan bahwa detik.com, khususnya detiktravel selalu menjalankan program yang diusung oleh pemerintah, termasuk gerakan ramah pariwisata yang menghimbau seluruh media online untuk menginformasikan citra positif terkait wisata Indonesia.

Peran detik.com dalam merepresentasikan budaya Suku Sasak di Desa Sade juga dapat dilihat lebih dalam dengan mengaitkan hasil analisis dengan konsep jurnalisme perjalanan. Untuk menganalisis pemberitaan wisata di portal berita detik.com, peneliti menggunakan konsep jurnalisme perjalanan yang menurut Hanusch harus dimiliki oleh jurnalisme perjalanan, yaitu representasi budaya asing, standar etika, orientasi pasar dan aspek motivasi.

Pertama, representasi budaya asing. Mengingat Desa Sade merupakan desa yang lekat hubungannya dengan budaya Suku Sasak, maka budaya menjadi hal yang dominan dalam teks yang disampaikan oleh detik.com, khususnya budaya eksotis. Namun, detik.com luput merepresentasikan sisi lain dari budaya Suku Sasak yang telah tergerus modernisasi. Sehingga representasi budaya asing dalam konsep jurnalisme perjalanan belum sepenuhnya dilakukan.

Kedua, standar etika. Berdasarkan hasil wawancara dengan Redaktur Pelaksana detiknews dan Redaktur Pelaksana detiktravel, mengklaim bahwa dalam memproduksi berita, detik.com selalu berpedoman pada Kode Etik Jurnalistik dan UU No. 40 Tahun 1999. Sayangnya, peneliti melihat beberapa teks merupakan bentuk laporan yang mengarah pada bentuk promosi untuk menarik perhatian pembaca dan artikel yang dibuat oleh penulis lepas bersifat subjektif.

Ketiga, orientasi pasar. Peneliti menilai bahwa detik.com cenderung mengedepankan teksteks yang menyuarakan kesenangan penulis dalam mengulas tempat wisata. Padahal, bentuk laporan perjalanan tidak sekadar menginformasikan kesenangan penulisnya. Meski demikian, Redaktur Pelaksana detiktravel menyebutkan bahwa target artikel yang dibuat dalam bagian D’Travelers Stories memiliki target kaum milenial.

Keempat, aspek motivasi. Teks berita Desa Sade yang dibuat oleh detik.com cenderung mengutamakan kesenangan penulis saat mengunjungi Desa Sade. Sementara tanggung jawab kepada publik yang disebutkan Hanusch dalam konsep jurnalisme perjalanan cenderung diabaikan. Saat melaporkan berita perjalanan, penulis seharusnya tidak hanya mengungkap apa yang ada dipermukaan, tetapi menggali lebih dalam terkait wisata yang hendak diulas.

Berdasarkan analisis konsep jurnalisme perjalanan, peneliti menilai keempat dimensi jurnalisme perjalanan yang disebutkan oleh Hanusch belum sepenuhnya dijalankan oleh detik. com. Detik.com hanya berperan mengungkapkan sisi positif dari Desa Sade yang mengarah pada kegiatan promosi. Sejalan dengan klaim detik.com terkait detik.com yang berperan memajukan budaya Indonesia, nampaknya pemahaman budaya yang ditujukan untuk mengedukasi pembaca cenderung mengunggulkan sisi positif untuk menarik perhatian pembaca agar mau mengunjungi Desa Sade, sehingga perubahan budaya cenderung diabaikan.

\section{SIMPULAN}

Produksi wacana budaya Suku Sasak dalam pemberitaan Desa Sade menunjukkan representasi detik.com sebagai media yang turut memajukan budaya Indonesia dengan menampilkan keunikan dari budaya Suku Sasak Sade melalui kata-kata, metafora dan tata bahasa. Detik.com menghegemoni pembaca terkait wacana budaya Suku Sasak yang dianggap sebagai budaya unik dan belum tergerus modernisasi dalam level teks. Representasi budaya unik menunjukkan detik.com sebagai media yang merepresentasikan budaya Suku Sasak sebagai wacana poskolonial. Pada level praktik wacana, produksi berita Desa Sade pada 
portal berita detik.com ditujukan untuk memajukan budaya Indonesia. Sementara pada level sosiokultural, aspek makro memengaruhi detik.com dalam merepresentasikan budaya Suku Sasak di Desa Sade. Pemunculan citra positif Desa Sade yang diproduksi oleh detik.com mengarah pada bentuk hiburan, promosi dan edukasi. Sementara perubahan budaya akibat modernisasi cenderung diabaikan, sehingga yang muncul dalam pemberitaan Desa Sade hanya sekedar keunikan budaya Suku Sasak. Peran media untuk memenuhi tanggung jawab kepada publik berdasarkan konsep jurnalisme perjalanan belum sepenuhnya dilakukan oleh detik.com.

Pemaparan terkait perubahan budaya Suku Sasak akibat modernisasi kiranya perlu disampaikan oleh media untuk menambah pemahaman pembaca, dibandingkan hanya sekadar menyampaikan kesenangan pribadi para penulisnya. Keterbatasan peneliti dalam menganalisis berita Desa Sade berpengaruh pada hasil penelitian yang kurang mendalam. Maka, penelitian terkait wisata Desa Sade masih bisa dilakukan untuk memperdalam hasil penelitian ini, baik di media yang sama maupun media lain. Penelitian terkait analisis wacana kritis yang berhubungan dengan pemberitaan wisata dalam merepresentasikan suatu tempat wisata masih perlu dilakukan untuk menambah kajian akademis, khususnya bidang jurnalisme perjalanan. Portal berita detik.com dalam mempublikasikan artikel wisata dari para penulis lepas juga dapat dikaji lebih dalam untuk memperdalam perbedaan antara jurnalis perjalanan dengan penulis perjalanan.

\section{DAFTAR PUSTAKA}

Aksan, H. (2017). Kamus Bahasa Indonesia (II; I. Kurniawan, Ed.). Bandung: Penerbit Nuansa Cendekia.

Amali, M. T. F., \& Mursito. (2016). Konstruksi media cetak Kompas dalam berita aktivitas pariwisata Indonesia (Studi analisis wacana terhadap teks berita pariwisata di harian umum Kompas periode Januari 2016) (Universitas Sebelas Maret). Universitas Sebelas Maret. Diakses dari https://digilib.uns.ac.id/dokumen/detail/56212/

Anggraeni, M., \& Syas, M. (2019). Representasi pariwisata di Kabupaten Tojo Una-Una, Sulawesi Tengah pada Majalah Destinasi Indonesia. Mediakom: Jurnal Ilmu Komunikasi, 3(2), 154-163. https://doi.org/10.35760/mkm.2019.v3i2.2338

Antalina, N. P. D. (2019). Tradisi adat Desa Sade yang bikin tercengang. Diakses February 20, 2020, dari detiktravel website: https://travel.detik.com/cerita-perjalanan/d-5390869/ tradisi-adat-desa-sade-yang-bikin-tercengang

Fadhillah, E., Sjafirah, N. A., \& Basith, A. A. (2019). Pengantar kajian jurnalisme wisata. In P. M. Yusuf (Ed.), Pariwisata Berkelanjutan (1st ed., pp. 240-251). Bandung: Unpad Press.

Fairclough, N. (1995). Critical discourse analysis: The critical study of language. New York: Longman Publishing.

Fauzan, U. (2014). Analisis wacana kritis dari model Fairclough hingga Mills. Jurnal Pendidik, 6(1), 123-137. Diakses dari https://www.academia.edu/13372775/Analisis_Wacana_ Kritis_dari_Model_Fairclough_hingga_Mills

Hanum, I. L. (2019). Kosakata Bahasa Indonesia (M. S. Santhi, Ed.). Yogyakarta: PT Penerbit Intan Pariwara.

Hanusch, F. (2010). The dimensions of travel journalism: Exploring new fields for journalism research beyond the news. Journalism Studies, 11(1), 68-82. https://doi. org/10.1080/14616700903290569

Hanusch, F. (2011). Representations of foreign places outside the news: An analysis of Australian newspaper travel sections. Media International Australia, 138(1), 21-35. https://doi.org/10.1177/1329878X1113800105 
DOI: $10.24198 /$ jkj.v5i1.31320

Jorgensen, M. (2012). Discourse analysis as theory and method. London: Sage Publications.

Krisdinanto, N. (2014). Anomali dan teori hirarki pengaruh terhadap isi media. Komunikatif, 3(1), 1-18. Diakses dari http://journal.wima.ac.id/index.php/KOMUNIKATIF/article/ view/1243

Reportase Trans TV. (2019). Melihat lebih dekat kehidupan Suku Sasak di Desa Sade Lombok Tengah. Diakses February 20, 2020, dari detiktravel website: https://travel.detik.com/ video/190226030/melihat-lebih-dekat-kehidupan-suku-sasak-di-desa-sade-lomboktengah

Rukajat, A. (2018). Pendekatan penelitian kualitatif (Qualitative research approach). Yogyakarta: Penerbit Deepublish.

Safitri, E. (2019). Dengar cerita tradisi kawin culik orang Sasak, Mufidah Kalla: Unik sekali. Diakses February 20, 2020, dari detiknews website: https://news.detik.com/ berita/d-4665749/dengar-cerita-tradisi-kawin-culik-orang-sasak-mufidah-kalla-uniksekali

Said, E. (1979). Orientalism. United States: Random House, Inc.

Said, E. (1993). Culture and imprealism (T. Eagleton, Ed.). New York: Vintage Books.

Sari, N. K., \& Nugroho, S. (2018). Dampak sosial budaya pengembangan Dusun Sade sebagai dusun wisata di Kabupaten Lombok Tengah. Jurnal Destinasi Pariwisata, 6(1), 159164. https://doi.org/10.24843/JDEPAR.2018.v06.i01.p24

Sukandar, P. A. (2017). Menggagas pelestarian permukiman tradisional Dusun Sade sebagai lansekap budaya yang mampu mengantisipasi kebutuhan penghuninya. Mintakat: Jurnal Arsitektur, 18(2), 77-86. https://doi.org/10.26905/mintakat.v18i2.1687

Sulhan, M. (2017). Makna destinasi wisata di dunia: Studi atas gambaran dunia maya dan fakta empirik destinasi wisata. Channel, 5(2), 123-142. https://doi.org/10.12928/channel. v5i2.7980

Zaakiyah, H. (2019). Tradisi-tradisi super unik dari Desa Sade. Diakses February 20, 2020, dari detiktravel website: https://ravel.detik.com/cerita-perjalanan/d-5389464/tradisi-tradisisuper-unik-dari-desa-sade

Zakaria. (2018). Desa Sade sebagai tujuan wisata budaya di Kabupaten Lombok Tengah NTB. Yogyakarta. https://doi.org/10.31219/osf.io/p54rq

Zulfatirahmi, S. (2018). Representasi eksotisme dalam pemberitaan destinasi wisata Indonesia (Analisis teks Majalah Travel Club Magazine dan DestinAsian Indonesia edisi JuniSeptember 2017) (Universitas Islam Indonesia). Universitas Islam Indonesia. Diakses dari https://dspace.uii.ac.id/handle/123456789/10117 